\title{
Possibilities of developing sheep which suckle from several teats
}

\author{
K. MAIJALA ${ }^{1}$ and B. KYLE ${ }^{2}$ \\ ' Agricultural Research Centre, Department of Animal Breeding, \\ 31600 Jokioinen, Finland \\ ${ }^{2}$ Invermay Agricultural Centre, Ministry of Agriculture \& Fisheries \\ Private Bag, Mosgiel, New Zealand
}

\begin{abstract}
Because of the increasing need for ewes which can rear more than two lambs adequately and without shepherding, studies were made in Finland (F), New Zealand (N. Z.) and Ireland on criteria relating the development of such ewes. The Finnish study was based on small trials in 1963 - 66 and in 1985-88 and on field data from the 1980's. Data of Vainikainen (1945) was also used. In N.Z., a more systematic experiment has been carried out since 1984, while in Ireland a small study of teat parameters was made in 1985.

The frequency of ewes with supernumerary teats (ST) in Finnsheep and Coopworth was ca. $20 \%$. The frequency of six-teated animals increased with selection for teat number. In Finland, about $1 / 2$ of the 4-teated ewes had milk-yielding STs. Six-teated ewes in N.Z. gave $30-40 \%$ of their daily milk from the STs. The N.Z. Coopworths seemed to have a mmultiple lamb imagen; multiple lambs tended to be closely bonded and sucked together, leading to higher success rates than when sucking individually. Heritability of teat number in N.Z. was 0.6. The lengths of STs were more variable than those of main teats, and their mean length ca. half of that of main teats. The average distance of STs from the main teats in Finnish trials was ca. $20 \mathrm{~mm}$ (range $1-50 \mathrm{~mm}$ ); the length and separation of teat pairs were correlated, although this was not the case in several flocks studied in Ireland.
\end{abstract}

Index words: supernumerary teats, teat length, teat distance, suckling behaviour, teat damage, functional teats, heritability

\section{Introduction}

The relative importance of meat in sheep production has generally increased during the last decades. Hence, attention has been paid to increasing the litter sizes (LS). One has aimed at achieving two lambs per ewe, in some cases even more. Because of the variation in LS, even an average of two lambs presupposes a considerable number of larger litters. Artificial rearing has been applied at many places to the extra lambs during the first weeks of their lives. This is costly, however, and so the need for ewes which can rear more than two 
lambs evenly and without human labour has increased. In case this would be possible, also the general target level concerning LS might be increased.

The purpose of this paper is to relate and discuss experiences obtained from field observations and trials in Finland and N. Z. It will mainly concentrate on the practical aim of producing ewes with more than two functional teats, but factors and criteria affecting the achievement of this goal will also be discussed, and the main problems to be researched in future highlighted.

\section{Earlier studies}

The inventor of telephone, Dr. Bell (2) is believed to be the first who paid attention to supernumerary teats (ST). After having observed multi-nipples in his Nova Scotia flock, he found the trait to be highly heritable and easy to increase. The mean number of teats per ewe in his flock increased from 2.27 to 5.40 between 1890 and 1913. Mrs. Bell continued the trials in 1915-23, aiming at welldeveloped extra teats which would produce useful amounts on milk. She had 16 ewes in which the extra teats were of almost normal size, yielded milk and had evidently been sucked by their lambs.

Castle (4) analyzed the records made by Bell. When both parents had 2, 4 and 6 teats, the means of offspring were 2.22, 3.74 and 5.23 , resp. However, considerable variation was left among the progeny of 6-teated parents. Some sheep from the flock were taken to the N.H. Experiment Station for further studies. These confirmed that teat number was highly heritable, but in nearly every case the additional teats were small and non-functional (14). Ritzman also proposed an explanation of the mode of inheritance based on three pairs of genes for gland development and three gene pairs for teat number. He produced good agreement between the expected and actual numbers of offspring having varying degrees of teat and gland development.
Another trial was carried out by Miller (10) at Rothamsted, England. Two 4-teated rams originating from Bells' flock and ewes with four very well developed teats were used to compare their mothering ability with that of two-teated ewes. It was concluded that although most of the ewes gave some milk from four teats after lambing, their lambs did not grow faster than lambs from normal ewes.

Data from sheep descending from Bell's flock were also used by PHILLIPS et al. (12) who found that response was low when selection was limited to only 4 teats, whereas BELL (2) used sheep with up to 6 teats. Like BELL, PHILlips et al. noted that extra teats did not increase the ewe's milk capacity (by visual assessment only). On the basis of anatomic studies they suggested that the STs were not connected to the primary milk producing tissue, hence yield was too low to sustain lambs or enhance lamb growth.

The inheritance of multiteat condition was also studied in Russia by Popova and KaRdymovich (13). They proposed a similar mode of inheritance in Russian breeds as in USA (14). They concluded that it is due to the action of a single gene; two teats being due to its allele in the homozygous condition and ewes with intermediate teat development being heterozygotes. WASSIN (17) obtained good monogenic ratios on this hypothesis. Popova et al. (13) also suggested that the occurrence of more than four nipples is due to a modifier which acts only in the presence of a single gene. Kovnerev (ref. 15) found 3-4-teated Romanov ewes to have given 0.3 more lambs per litter, $0.65 \mathrm{~kg}$ heavier litters at birth and $6.6 \mathrm{~kg}$ heavier litters at 100 days than 2-teated ewes.

In Finland, VAINIKAINEN (16), having heard about the existence of 4-teated ewes in 1936, started experiments to clarify its inheritance. He crossed and back-crossed 2- and 4-teated animals, and concluded that the occurrence of extra teats is determined by a single dominant gene. He observed considerable variation in the size of STs and in their distance from the 
main teats. Many STs were blind, and only 10 of 80 ewes had STs which yielded milk. These ewes did not appear to possess a greater milk-producing capacity than 2-teated ewes. VAINIKAINEN (16) felt that the STs were generally too close to the main teats to allow multiple sucking to occur, and therefore had no practical value.

During the 1950's, increased interest in LS reflected the growing importance of meat production. Rearing more than two lambs per ewe was desirable in many situations, and it was felt this might be facilitated by having more functional teats per ewe. Hence, the senior author made a small trial in Finland in 1963-66 (9). It showed that teat number can be increased easily and that the size of the extra teats and their separation from main teats vary.

In the 1980's, interest in the trait appeared in Australia, U.K., Norway, Ireland, N.Z. and the U.S.A., from where the senior author was approached. In U.K., KING (6) discussed the trait and requested information about animals with well developed STs. CARDELL (3) reported that a British farmer (P. CAUNTER) had been selecting for the trait since 1971 and whose flock of 425 ewes had about 80 ewes with four functional teats. His selection criteria and policy were described. CAtchpole (5) and Patterson (11) also discussed Bristish experiences.

In Ireland, Kyle and Hanrahan (7) sampled various flocks which had not been selected for teat number. Mean teat number was 3.2 and varied very little among the 5 breeds examined. $51 \%$ of ewes had at least four teats. Supernumerary teat length (STL) was clearly dependent on age and did not appear to be correlated with main teat length or separation distance. The C.V. of STL was 0.35 , and that of main teat length 0.14 . STL had no effect on lamb growth rate and seemed therefore to be of little or no consequence for the development of main secretory mass. However, the milk yields of a small group of Finn ewes following artificial induction of lactation were significantly related to STL (7).

\section{Finnish studies and observations}

\subsection{Materials and methods}

The following sets of data were collected and used to assess different aspects of multinippled condition:

FA $=$ Trial at Agricult. Research Centre (ARC), Jokioinen, 1985-88. About 10 ewes, which had been seen to suckle more than two lambs simultaneously, were acquired from private flocks in 1983. In 1985-87, 36 matings of 4-teated rams to these and similar ewes were recorded, plus about 10 matings of 4-teated ewes with 2-teated rams. The lengths and teat distances of mothers and lambs were measured after lambing.

FB = Finnish Sheep Breeders' Association (FSBA) registered ewes by 1982. A sample of 3324 registered ewes was studied to estimate the frequency of 4-teated ewes (9). The teat numbers were recorded, and owners of 4-teated ewes were sent questionnaires about their sheep.

$\mathrm{FC}=$ Finnish registered ewes in 1982-87. The numbers of teats were recorded from 1745 Finnsheep ewes registered in 198287 by the FSBA.

$\mathrm{FD}=$ Private Finnish flock ewes in 1988. In an article on 4-teated ewes, a questionnaire was published in Finnish sheep journal in 1988 (8). Flock owners were asked to provide information about 4-teated Finnsheep. Parameters sought included the identity, parentage, age and LS of the ewes, and numbers, lengths, distances and functioning of the teats. Replies were obtained from 15 flocks, concerning 197 multi-teated ewes.

$\mathrm{FE}=$ Old data from 1940, using teat length and distance measurements of the 80 ewes in VAINIKAINEN'S (16) report.

Because of the small volume of most of the data sets and their nature, only simple statistical analyses (frequencies, means, S.D. and r) were performed. All results are given here, despite the lack of data in some cases. 


\subsection{Results}

\subsubsection{Frequency of ewes with supernumerary teats}

Teat number frequencies in registered ewes are shown in Table 1. The total frequency of ewes with more than two teats has increased from $17.1 \%$ (FB data) to $20.1 \%$ (FC set), and the frequency of ewes with exactly four teats has also increased. These changes may result from a difference in recording accuracy. Four 5-teated and five 6-teated ewes were recorded.

The proportions of ewes giving milk from the front $(\mathrm{F})$ teats are shown in Table 2. Although 13 ewes from the FB (1982) survey showed appreciable front teat yields, 50 to $75 \%$ of the known cases gave no milk.

Of the 28 owners in the FB-data, who gave their opinion, about half felt that front teats had improved the suckling ability of their ewes, while the other half had seen no improvement. Most $(90 \%)$ thought the extra teats did no harm, while $10 \%$ felt they did. The managers supplying the FA-data have not yet found appreciable amounts of supernumerary milk, or separate milk glands.

\subsubsection{Teat lengths}

Lengths of both right and left, rear and front teats of ewes were available from several sets of data. Right and left sides did not generally differ, so their averages were used for the front and rear teat lengths. Values between data sets are not comparable due to measuring differences between persons. It can be seen in Table 3 that there was a lot of variation in the length of the front teats, which usually appear as the smaller, supernumerary teat pair. The S.D. was larger than for rear teats, and the C.V. was almost three times as high. In some cases the front teats were almost as long as the rear, while in others they were difficult to see. On average, the front teats were about half as long as the rear teats. Within flocks, the average front teat length of 30 ewes which gave some milk from them was 2.7 $\mathrm{mm}$ above the corresponding flock means.

Teat lengths of lambs (FA data) were about

Table 1. Teat frequencies from two samples of registered Finnsheep ewes. (FB and FC, see paragraph 3.1 ).

\begin{tabular}{lcrrrr}
\hline Group of ewes & \multicolumn{2}{c}{ FB (-1982) } & & \multicolumn{2}{c}{ FC (1982-87) } \\
\cline { 2 - 3 } \cline { 5 - 6 } & No. of ewes & $\%$ of ewes & & No. of ewes & $\%$ of ewes \\
\hline Ewes with 2 teats & 1992 & 82.9 & 7.9 & 1244 & 80.0 \\
Ewes with 4 teats & 189 & 9.2 & 220 & 14.2 \\
Ewes with other no. of teats & 222 & 403 & & 151 & 5.9 \\
Total with recorded no. of teats & 921 & & 190 & 100.0 \\
Total with number not recorded & 324 & & 175 \\
Total size of sample, ewes & & & \\
\hline
\end{tabular}

Table 2. Numbers of 4-teated Finnsheep with milk-yielding supernumeraries in three separate sets of data.

\begin{tabular}{|c|c|c|c|c|c|c|c|}
\hline \multirow[b]{2}{*}{$\begin{array}{l}\text { Amount of } \\
\text { milk from } \\
\text { extra teats }\end{array}$} & \multicolumn{2}{|c|}{ FE (1940) } & \multicolumn{3}{|c|}{ FB (1982) } & \multicolumn{2}{|c|}{ FD (1988) } \\
\hline & $\begin{array}{c}\text { No. of } \\
\text { ewes }\end{array}$ & $\begin{array}{l}\% \text { of } \\
\text { known } \\
\text { cases }\end{array}$ & $\begin{array}{l}\text { No. of } \\
\text { ewes }\end{array}$ & $\begin{array}{l}\% \text { of } \\
\text { ewes }\end{array}$ & $\begin{array}{c}\% \text { of } \\
\text { known } \\
\text { cases }\end{array}$ & $\begin{array}{c}\text { No. of } \\
\text { ewes }\end{array}$ & $\begin{array}{c}\% \text { of } \\
\text { known } \\
\text { cases }\end{array}$ \\
\hline Appreciably & - & - & 13 & 12 & 24 & - & - \\
\hline A little & 10 & 13 & 16 & 16 & 29 & 50 & 25 \\
\hline No milk & 70 & 87 & 26 & 24 & 47 & 149 & 75 \\
\hline Not known & - & - & 54 & 48 & - & - & - \\
\hline Total & 80 & 100 & 109 & 100 & 100 & 199 & 100 \\
\hline
\end{tabular}


$1 / 4$ and their S.D. ca. $40 \%$ of the corresponding figures in ewes. The C.V. of both rear and front teats were relatively even larger. Also in lambs, the front teat length was about half of rear teats. In four of the 47 lambs the relative length exceeded $80 \%$.

\subsubsection{Distance between rear and front teats}

Means and variations of the distance between the front and rear teats are given in Table 4. The differences between the FE data and the rest may be a result of measuring technique, e.g. between the roots of teats instead of between the tips. The average rear-front distance for 29 ewes giving milk from their front teats was $1.5 \mathrm{~mm}$ above their flock means. In measured lambs the average distance was one-third and S.D. one-half that found in ewes.

\subsubsection{Correlations among teat lengths and placement}

Phenotypic correlations within flocks are shown in Table 5. The FA- and FD-data yielded significant values for the correlation between front and rear teat lengths in ewes, and also in lambs in the former set. Teat distance was positively correlated with front teat length in one set of ewe data. Teat distance and rear teat length were positively correlated in both ewes and lambs, but were not consistent.

Correlations between teat measurements of dams and the average of their lambs are shown in Table 6. Although the data were limited they show that the correlations were generally positive. Front teat length of the dam was significantly correlated with both rear (.47) and front (.58) teat length of the lambs.

\section{Studies in New Zealand}

\subsection{Material and methods}

In N.Z., about $20 \%$ of ewes have been found to have more than two teats in the few surveys conducted on unselected flocks. Because of the interest shown by N.Z. sheepfarmers in increasing lambing percentages to improve their economic survivability, the N.Z. Ministry of Agriculture and Fisheries began screening its flocks for multinippled ewes in the early 1980s. Two outstanding ewes and a 4-teated ram were supplied by a Coopworth Breeder, Mr. K. Dunlop, and a breeding trial was properly established in 1984 by the junior author. While a high level of Coopworth blood has been maintained to improve mothering ability, a Booroola Merino sire has been used to increase prolificacy and some Romney ewes have also been included.

The flock has increased in size from 22 ewes in 1984 to 100 at present, and the average teat number has increased from 3.4 to 3.8 . The multi-teated ewes present vary in supernumerary teat yield (STY) between 0 and $170 \mathrm{mls,}$ or 0 and $42 \%$ of the total milk yield. They comprise four, five, six and even eight-teated animals, while two, four, five and six-teated rams have been used to date. A number of two-teated ewes are maintained within the flock as controls.

In addition to teat frequencies, STYs were measured by emptying the udder using handstripping and the hand-stripping again after a four-hour period in yards separated from their lambs. This was done at Day 30 of lactation. Empty udder volumes were estimated by water displacement after milking, but the technique was considered too inaccurate and therefore discontinued. Udder types were designated on the basis of STY (see Table 8). WLR30 (total weight of surviving lambs on Day 30 of lactation, minus birthweight) and WLR70 (total weight of surviving lambs on Day 70 of lactation, minus birthweight) were used as production indices. WLR30 was used as an approximation of total milk production during early lactation, while WLR70 was a more generalized index incorporating dam, sire and offspring characters. Suckling behaviour of triplet-rearing ewes was monitored 
Table 3. Means and variations of teat lengths $(\mathrm{mm})$ in three sets of Finnish data.

\begin{tabular}{|c|c|c|c|c|c|c|c|c|c|c|}
\hline \multirow[t]{2}{*}{ Data set } & \multirow[t]{2}{*}{$\mathrm{n}$} & \multicolumn{4}{|c|}{ Rear teats (R) } & \multicolumn{4}{|c|}{ Front teats (F) } & \multirow{2}{*}{$\begin{array}{c}\mathrm{F} / \mathrm{R} \\
\%\end{array}$} \\
\hline & & Mean & Range & S.D. & C.V. & Mean & Range & S.D. & C.V. & \\
\hline \multicolumn{11}{|l|}{ EWES: } \\
\hline FE $(-40)$ & 77 & 25.5 & $10-30$ & 3.5 & 13.6 & 15.2 & $3-30$ & 5.5 & 36.1 & 59.4 \\
\hline FA $(-86-88)$ & 19 & 30.9 & $21-45$ & 5.9 & 19.2 & 14.3 & $3-26$ & 6.8 & 47.2 & 46.3 \\
\hline FD $(-88)^{*}$ & 71 & 29.4 & $20-42$ & 5.4 & 18.4 & 11.6 & $1-28$ & 6.3 & 54.4 & 39.5 \\
\hline Total & 167 & 27.8 & $10-45$ & 4.6 & 16.5 & 13.6 & $1-30$ & 6.0 & 44.1 & 48.8 \\
\hline \multicolumn{11}{|l|}{ LAMBS: } \\
\hline FA $(-86-88)$ & 47 & 7.7 & $3-16$ & 2.6 & 34.1 & 4.1 & $1-10$ & 2.5 & 61.9 & 52.9 \\
\hline
\end{tabular}

* includes differences between flocks (measurers)

Table 4. Means and variations of distance $(\mathrm{mm})$ between front and rear teats in Finnish studies.

\begin{tabular}{lcccrr}
\hline Data set & $\mathrm{n}$ & $\begin{array}{c}\text { Mean } \\
\mathrm{mm}\end{array}$ & $\begin{array}{c}\text { Range } \\
\mathrm{mm}\end{array}$ & $\begin{array}{c}\text { S.D. } \\
\mathrm{mm}\end{array}$ & $\begin{array}{c}\text { C.V. } \\
\%\end{array}$ \\
\hline EWES: & & & & & \\
FE (1940) & 77 & 9.6 & $1-20$ & 4.6 & 47.7 \\
FA (1986-88) & 19 & 22.5 & $3-42$ & 10.9 & 48.7 \\
FD (1988)* & 71 & 24.6 & $1-50$ & 12.9 & 52.5 \\
Total & 167 & 17.4 & $1-50$ & & 50.8 \\
LAMBS: & & & & & \\
FA (1986-88) & 93 & 7.6 & $0-19$ & 4.4 & 57.4 \\
\hline
\end{tabular}

* includes differences between flocks (measurers)

Table 5. Within-flock phenotypic correlations among teat lengths and R-F-distances in three sets of data.

\begin{tabular}{|c|c|c|c|c|}
\hline Correlated traits & $\begin{array}{c}\text { FE (1940) } \\
\text { (75 d.f.) }\end{array}$ & $\begin{array}{c}\text { FA }(1986-88) \\
(30 \text { d.f. })\end{array}$ & $\begin{array}{c}\text { FD (1988) } \\
\text { (50 d.f.) }\end{array}$ & $\begin{array}{l}\text { FA + FD } \\
(80 \text { d.f. })\end{array}$ \\
\hline \multicolumn{5}{|l|}{ EWES: } \\
\hline R-length $\times$ F-length & -.17 & $.58^{* *}$ & $.31^{*}$ & $.44 * *$ \\
\hline$-n-\times$ R-F-dist. & -.02 & .25 & .07 & .16 \\
\hline F-length $\times-n-$ & .05 & $.36^{*}$ & .07 & .12 \\
\hline LAMBS: & & (43 d.f.) & & \\
\hline R-length $\times$ F-length & & $.63^{* *}$ & & \\
\hline$-n-\times$ R-F-dist. & & $.31^{* *}$ & & \\
\hline F-length $\times-n-$ & & -.01 & & \\
\hline
\end{tabular}

for 12-hour periods several times during lactation: duration, frequency and success of sucking bouts were recorded; also the number of lambs present and the side of the ewe sucked. Sucking success was measured as the proportion of bouts at which lambs were permitted to suck. Statistical methods included simple means and frequencies, least-squares, maximum likelihood and multiple regression analyses.
Table 6. Within-year phenotypic correlations between teat parameters of dams and their lambs' averages (mean 2.04 lambs/dam/yr.); FA-data (19 d.f.).

\begin{tabular}{lccc}
\hline $\begin{array}{l}\text { Parameter } \\
\text { of dams }\end{array}$ & \multicolumn{3}{c}{ Parameter of lambs } \\
\cline { 2 - 4 } & $\begin{array}{l}\text { R-teat } \\
\text { length }\end{array}$ & $\begin{array}{c}\text { F-teat } \\
\text { length }\end{array}$ & $\begin{array}{c}\text { R-F- } \\
\text { distance }\end{array}$ \\
\hline R-teat length & .29 & .12 & .39 \\
F-teat length & $.47^{*}$ & $.58^{* *}$ & .28 \\
R-F-distance & -.06 & .16 & .06 \\
\hline
\end{tabular}




\subsection{Results}

\subsubsection{Suckling behaviour}

Insufficient numbers of triplet-rearing ewes were available to fully compare the various udder types. Despite this, it was felt the results were most relevant to the multinipple trait (see Table 7 and Fig. 1). Despite sucking success being highest $(69 \%)$ when two triplets were present, there were most commonly three lambs present at any one attempt (41 \%). Consequently, of the $60 \%$ of bouts which were successful for triplets generally, nearly half were the result of three-lamb bouts.

There was a surprisingly low success rate for triplets attempting to suck individually. Triplet litters were very closely bonded and slept, fed and played together most of the time. The preference of Coopworth ewes to feed two or three lambs at once suggested that imprinting behaviour was involved.

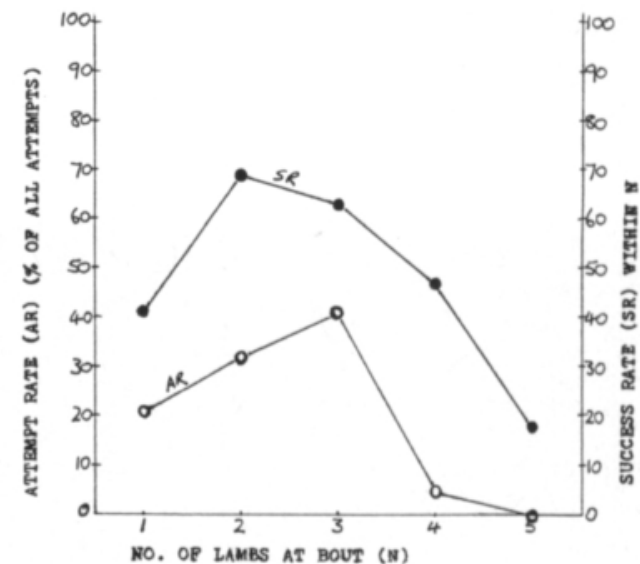

Fig. 1. Attempt rate + success rate of suckling triplets (on own dam).

Multiple lambs did not appear to starve from becoming "fixed" onto supernumerary teats. Suckling data and observations suggested that starvation was caused by a weak lamb being less competitive than its siblings at three-

Table 7. Numbers of attempts, successes and success rates of triplet lambs within number of lambs present at sucking bout.

\begin{tabular}{lcccccc}
\hline Parameter & \multicolumn{5}{c}{ No. of lambs attempting to suck at once } \\
\cline { 2 - 7 } & 1 & 2 & 3 & 4 & 5 & Total \\
\hline No. of attempts/hour & .96 & 1.44 & 1.87 & .24 & .009 & 4.52 \\
No. successes/hour & .39 & 1.00 & 1.18 & .11 & .002 & 2.68 \\
Success rate (SR), & $41 \%$ & $69 \%$ & $63 \%$ & $47 \%$ & $18 \%$ & - \\
\% of all attempts & $21 \%$ & $32 \%$ & $41 \%$ & $5 \%$ & $0 \%$ & $(100)$ \\
Overall success (C $\times$ D) & $8.6 \%$ & $22.1 \%$ & $25.8 \%$ & $2.4 \%$ & $0 \%$ & 58.9 \\
Ratio of overall & 0.15 & 0.37 & 0.44 & 0.04 & 0.00 & \\
success (C $\times$ D/58.9) & & & & & & \\
\hline
\end{tabular}

Table 8. Designation of Udder Type according to STY (mls milk/4 hrs), and Least-Squares regression model of WLR30 by Udder Type.

\begin{tabular}{lcccc}
\hline $\begin{array}{l}\text { Udder } \\
\text { Type }\end{array}$ & STY $(\mathrm{mls})$ & $\begin{array}{c}\text { No. lactations } \\
\text { recorded }\end{array}$ & WLR30 & S.E. \\
\hline 1 & 2-teated ews & 21 & 12.79 & 1.44 \\
2 & 0 & 61 & 13.36 & 0.36 \\
3 & $1-25$ & 23 & 13.39 & 0.59 \\
4 & $30-50$ & 7 & 15.65 & 2.83 \\
5 & $55-75$ & 4 & 15.29 & 1.06 \\
6 & $80-100$ & 2 & 12.15 & 1.39 \\
7 & $105-125$ & 2 & 12.98 & 1.98 \\
8 & $130-150$ & 4 & 12.98 & 1.98 \\
9 & $155-175$ & 12.79 & 1.44 \\
\hline
\end{tabular}

WLR30 $=$ total weight $(\mathrm{kg})$ of surviving lambs on day 30 of lactation minus birthweight. 


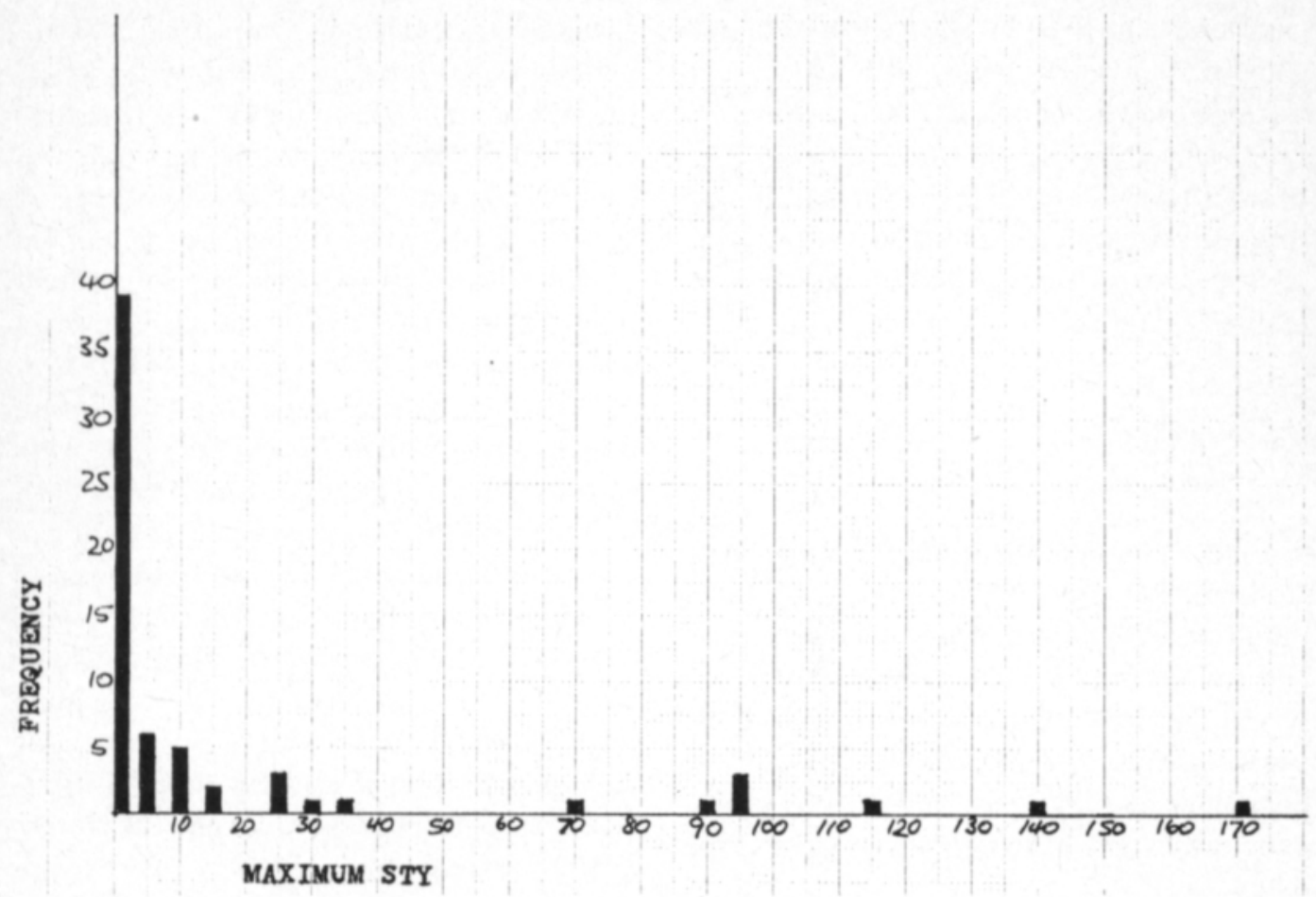

Fig. 2. Number of ewes within class of supernumerary teat yield.

lamb sucking bouts, and being unable to secure one of the two main teats. In addition, their success rate at one-lamb bouts was generally poor due to the "multiple lamb preference" of ewes, which meant that less vigorous triplets were most likely to obtain milk only at two-lamb bouts. This often proved more difficult with time. Such lambs were frequently observed by themselves, attempting to suck from their dams and other ewes from behind, usually when the ewe was grazing. They typically developed faecal-stained heads, had very poor growth rates and often died before weaning.

\subsubsection{Supernumerary teat milk yields (STY)}

STYs varied between 0 and $170 \mathrm{mls}$, or 0 and $42 \%$ of total milk yield (Table 8 ). Multivariate regression using total birthweight, ewe age, ram, sex of lambs, rearing rank on Day 30, STY and Uddertype revealed that
STY and Uddertype had no significant effects on WLR30 or WLR70. Least-Square models of WLR 30 by Uddertype are given in Fig. 3 and Table 8. Fig. 2 shows the distribution of

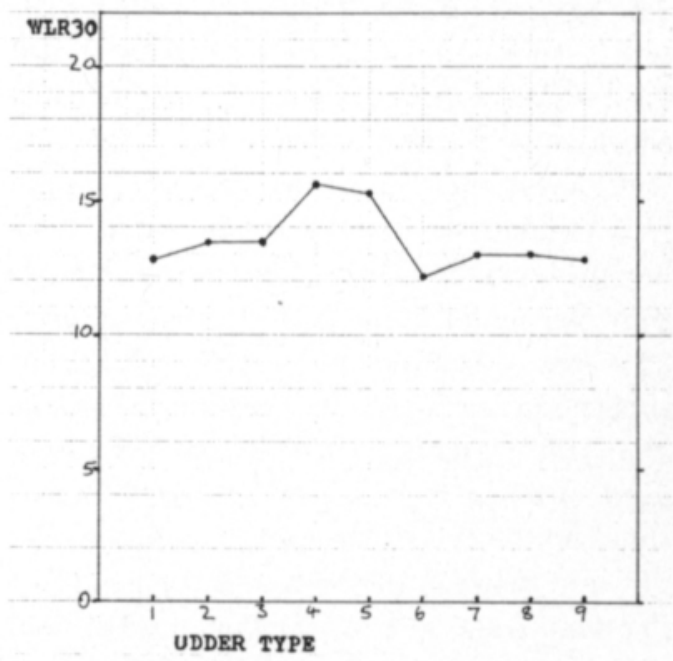

Fig. 3. Least-squares regression model of total weight of surviving lamb reared to Day 30 of lactation (WLR30) according to udder type. 
ewes according to STY. The frequency of outstanding individuals is low, although several 6-teated ewes do not appear as they have not produced lambs yet. The three best ewes (Fig. 2) each have six teats. Eighty percent of multinippled ewe milkings at Day 30 of lactation yielded $25 \mathrm{mls}$ or less of milk from the extra teats (Table 8).

\subsubsection{Anatomy of the supernumerary teats}

Supernumerary teats ranged in appearance from "slight warts» through to a large, functional state. Most commonly they were blind and rudimentary (" $2 \mathrm{~F} 2 \mathrm{R}$ ewes»). It was observed that STY tended to be least when the supernumeraries were near the edge of the mammary pad, and that fully functional supernumeraries were comparatively close to the main teats.

Although $2 \mathrm{~F} 2 \mathrm{R}$ ewes possessed only two functional teats, there was some evidence from WLR30 analysis and earlier milking studies that these ewes may have had slightly larger gland masses than ewes with other udder types. Fig. 3 and Table 8 show the relation between udder type and WLR30.

It was generally observed that STL increases with age and functional capacity, while the latter is also accompanied by an increase in teat base diameter. Six-teated ewes had noticeably short, squat primary and secondary teat pairs considering their functional capacity, but all were evenly-sized and did not appear to cause any problems for lambs. Teat measurements were not made in the N.Z. study, but there appeared to be no relation between length of supernumeraries and their distance from the main teats. Data (not shown) from 288 mixedaged ewes in Ireland comprising 4 breeds showed little evidence for any significant relationship between the STL and the length of the main teats, nor for the distance between main teats and the supernumeraries.

It became apparent during the course of the breeding programme that fully functional su- pernumeraries (yielding more than $100 \mathrm{mls}$ milk/4 hours) were associated with the sixteated state only. In this state two teat pairs were fully functional and one teat pair was rudimentary or of limited capacity. When all six teats appeared on the udder, the amount of milk secreted by each pair decreased anteriorally. The total STY of the middle and front teats appeared to be about two-thirds that of the hind teat-pair, giving a 40/60 ratio common in cows. Udders having only four, very even teats have been noticed; such ewes were, however, found to possess a pair of rudimentary teats in the crotch region. In these cases the amount of milk secreted declined posterially, but the rudimentary teats were non-functional due to their location. The four main teats showed a $60 / 40$ ratio in this case. One eight-teated ewe had supernumeraries located on both the anterior udder and the crotch. Despite rearing only a single in her first lactation, four-hourly teat-pair yields of 130, 75, and $20 \mathrm{mls}$ were measured on Day 30.

Supernumerary teats were not found to become larger and more functional due to either frequent sucking or impairment of the main teats. Ewes rearing triplets and suffering from severe main teat damage showed no increase in size or yield of their supernumeraries. The gland mass of supernumerary teats was generally very small and was adjacent to, but appeared independent from, the main secretory tissue.

\subsubsection{Teat damage}

Teat damage on Day 30 of lactation was assessed for each ewe by scoring the severity of cuts or sores on their teats as minor, medium or severe. From 135 assessments, medium or severe teat damage was evident in $2 \%, 28 \%$ and $34 \%$ of cases for single, twin and tripletrearing ewes, resp. It appeared that rearing rank had a greater effect than teat number on teat damage. The effect of teat number will be of great interest, however, when more sixteated ewes become available for study. 


\subsubsection{Heritability}

On the basis of midparent-offspring regression, the heritability of teat number was estimated as $0.60 \pm 0.07$. By separating the midparent term into its dam and sire components, the trait appeared to be inherited more strongly from females than from males. Similar results were obtained from parent-offspring regressions. There appeared to be a maternal environmental effect operating on lamb teat number, since the $\mathrm{h}^{2}$-estimate from dam- offspring regression was 1.16 .

Recorded STYs at day 30 of lactation were used to estimate the heritability of udder function. The records of 26 dam-daughter pairs were analyzed, and only dams possessing supernumerary teats were included. The regression coefficient was $0.66 \pm 0.12$, and the heritability again greater than unity. Despite these extremely high estimates, it was noted that the regression was close to that obtained for offspring teat number on dam teat number $(0.58 \pm 0.08)$.

\subsubsection{Progress}

An idea of the progress so far is obtained from the average teat numbers of ewes and rams mated, and of those of lambs born in different years (Table 9).

\section{Discussion and conclusions}

Attempts to select ewes which can suckle simultaneously more than two lambs and to study problems associated with it have been initiated in several countries. The Finnish and N.Z. studies reported here cover rather different aspects of the subject and therefore supplement each other to a great extent.

\subsection{Incidence of multinippled condition}

It has become clear that multinippled ewes can be found in many breeds and are independent of prolificacy. In Finnsheep and Coopworths the incidence of multinippled ewes ap-
Table 9. Mean teat numbers of ewes, rams and lambs born within groups.

\begin{tabular}{rrrrrr}
\hline Year & Ewes & $\mathrm{N}$ & Ram & Lambs & $\mathrm{N}$ \\
\hline 1984 & 3.4 & 22 & 4.0 & 3.8 & 45 \\
1985 & 3.6 & 42 & 5.0 & 4.0 & 82 \\
1986 & 4.0 & 38 & 6.0 & 4.2 & 53 \\
1986 & 2.0 & 9 & 2.0 & 2.3 & 12 \\
1986 & 4.0 & 8 & 4.0 & 3.2 & 14 \\
1987 & 3.9 & 11 & 6.0 & 4.1 & 38 \\
1987 & 2.0 & 18 & 2.0 & 2.6 & 11 \\
1987 & 4.0 & 8 & 6.0 & 4.2 & 18 \\
1987 & 4.0 & 12 & 4.0 & 3.7 & 29 \\
1987 & 4.7 & 3 & 4.0 & 4.0 & 7 \\
\hline
\end{tabular}

pears to be about $20 \%$, and even higher in some samples of Irish breeds. The trait occurs in both sexes with about equal frequency and is evident at birth. The average teat number in a flock can be readily increased by mating animals with more than two teats; both ewes and rams with six teats have been found.

The incidence of ewes with functional supernumeraries yielding large amounts of milk is less clear and in any case much lower than that of ewes with extra teats. Twelve percent of an old sample of 4-teated Finnsheep gave some milk from the extra teats, while the figure in a recent sample was $25-50 \%$.

\subsection{Milk production from extra teats}

The crucial question of the amount of milk yielded by supernumerary teats (STY) is still not fully resolved. The spectrum of phenotypes which exist appears to be mirrored by an equally large range in STYs. We can, however, report that the great majority of multinippled sheep so far examined have yielded little or no milk from the extra teats, and that the six-nippled state appears to be necessary before large, fully functional glands are evident. In that state, extra teat pairs have been measured yielding $170 \mathrm{mls}$, or $40 \%$ of the total milk produced over a four-hour period at peak lactation.

Dissection of udders by PHiLlips et al. (12) and in the N.Z. study indicates that the gland mass associated with each supernumerary teat 
is usually very small and is generally adjacent to, but independent from the gland mass of its main teat. The data collated so far indicate that teat pairs are generally even-sized, and that single supernumeraries are relatively uncommon. There is some evidence that supernumerary teat length (STL) is related to the length of the main teats, and conflicting evidence that STL is related to distance from the main teats. The fact that extra teats increase in size similar to the main teats throughout the ewe's life (i.e. the relative size difference remains constant) indicates that the smaller teats are also under hormonal influence. The Finnish report that supernumeraries which yielded milk were $2.7 \mathrm{~mm}$ longer than those that did not, suggests that STL may be positively related to the amount of underlying secretory tissue.

The evidence from N.Z. which suggests the presence of supernumerary teats may be correlated with an increase in udder size is most interesting. It implies that the intermediate supernumerary condition may be optimal for total milk yield, and that the presence of heterozygotes in many sheep flocks is a result of indirect selection.

There is most definitely a need for supernumerary yields to be accurately measured under standard conditions (e.g. 4-hourly yields on Day 30 of lactation). While such methods may present practical difficulties, they are nevertheless essential if accurate measurements and comparisons are to be made.

\subsection{Suckling behaviour and teat damage}

The suckling behaviour studies performed in N.Z. suggest that triplet-rearing Coopworth ewes have a mmultiple lamb image" which strongly influences their suckling behaviour. During that 3-year study, triplet lambs within a litter tended to stay close together, often far from their dam, and most often sucked their dam simultaneously. It resulted in higher success rates for multiple suckings, and $44 \%$ of all successful bouts involved three lambs.
The damage was associated quite strongly with the number of lambs reared in the N.Z. study. The presence of functional supernumeraries is expected to have an important bearing on teat damage, as lambs invariably utilize all the available functional teats $(3,11)$. Even single lambs have been observed in the N.Z. study to suck all six teats at one bout.

\subsection{Heritability}

The mode of inheritance for the multinipple trait has yet to be conclusively proven, due mainly to a lack of controlled matings involving six-teated animals. However, VAINIKAINEN'S (16) single gene hypothesis, RITZMAN'S (14) multigenic hypothesis and heritability estimates by KYLE (unpublished), have all shown that the trait is highly heritable. It seems logical that six teats and two teats represent homozygous states of the trait, and four teats a heterozyugous one; a major problem, however, lies in explaining the apparently continuous variation in supernumerary size. The observation that the six-nipplud phenotype has at least two forms may enhance our understanding of mammogenesis in multinippled sheep.

The similarity of the two regression coefficients for dam-daughter STY $(0.66)$ and damdaughter teat number $(0.58)$ gives reason to assume that the heritability of milk yield from extra teats is inherited about equally with teat number, and is perhaps controlled by the same gene complex. These figures were based on limited numbers, however, and should be treated with caution.

\subsection{Selection criteria and policies}

Because of the difficulty in ewes, and the impossibility in rams and lambs of estimating the milk yield, the use of teat lengths and distances as predictors is of interest. The Finnish data showed the C.V. and mean of STL to be respectively twice and half those of the main teats. The C.V. was similar to that obtained in Ireland (7). STL of Finnish ewes giv- 
ing milk was nearly $3 \mathrm{~mm}$ above flock means. This could be an effect of lamb sucking, but it is unlikely. STL was not found to be correlated with growth rate of lambs in Ireland, but it was correlated with the amount of milk yielded following artificially induced lactations (7). The C.V. and mean teat lengths of lambs were respectively 1.3 and 0.25 times those found in ewes, and the lengths showed significant correlations with those of ewes. All of these data require confirmation with other groups of animals.

The distance of front teats from the main ones is important for the sucking of several lambs simultaneously. The Finnish data showed wide ranges $(1-50 \mathrm{~mm}$; mean $=20$ $\mathrm{mm}$ ), and significant correlations between distance and teat lengths. These data also require confirmation as no relation was observed in Ireland. It is important that genetic correla- tions can be obtained also, necessitating large numbers of animals.

Although the N.Z. data suggest that the multinipple trait is inherited more strongly from dams than sires, it would seem desirable to retain multinippled rams for progenytesting as some sires may pass on the trait better than others.

The multinipple trait has been shown to be highly heritable, and in its extreme form eminently suited to multiple lamb rearing.

Reduced competition between lambs for teats, better family bonding and lower levels of teat damage are seen as its main benefits. While total milk yield may be improved by extra teats, there is not yet strong evidence linking the two. The authors believe that in time the multinipple trait can be developed to good effect, provided the generation of six-teated animals is easily accomplished.

\section{References}

1. AnONYmous, 1987. Performance of four teat ewes under study. Farmweek, June 19, 1987: 5.

2. BELL, A.G., 1923. Saving the sex-nippled breed. J. Hered. 14: 99-111.

3. Cardell, K., 1987. Breeding four teats. The Sheep Farmer, May-June, 1987: 28-29.

4. Castle, V.E., 1924. The genetics of multinippled sheep. J. Hered. 15: 75-85.

5. Catchpole, P., 1985. Four teats better than two. Sheep Special.

6. KING, J.W.B., 1985. Look for four teats! The Sheep Farmer, Sept. 1985.

7. Kyle, B. \& Hanrahan, J.P., 1985. Supernumerary teats in sheep. Animal Production. Grange/Dunsinea, Moorepark \& Western Res. centres, Res. Rep. 1985: 12-13.

8. Maijala, K., 1988. (Increased interest in four-teated ewes). In Finnish. Lammastalous 1/1988: 15-23.

9. Maijala, K. \& Rautala, H., 1982. Occurrence of multiple teats in Finnsheep. 32th Ann. Meet. EAAP, Comm. Sheep \& Goats (Leningrad): 2 pp.

10. Miller, H.G., 1934. Four-nippled sheep. Scot. J.

Agr. 17: 79-85.

11. Patterson, E., 1986. Four working teats. The Sheep Farmer, May-June, 1986: 20.

12. Phillips, R.W., Schott, R.G. \& Spencer, D.A., 1945. The genetics, physiology and economic importance of the multinipple trait in sheep. USDA Tech. Bull. 909: 16 pp.

13. Popova, E.T. \& Kardymovich, E.I., 1932. (Polymastia, its manifestation, inheritance and association with fertility and milk yield. Genetics of Sheep: 63-91) (In Russian), Anim. Breed. Abstr. 1: 19-20.

14. Ritzman, E.G., 1933. The multinipple trait in sheep and its inheritance. N.H. Agr. Exp. Sta. Tech. Bull. 53: $32 \mathrm{pp}$.

15. SuONnE, B., 1969. (On the prolific mothers and on the development rates of lambs of Romanov breed). In Finnish. Lammastalous 3/1969: 21-24.

16. VAINIKAINEN, V., 1945. On the heritability of supernumerary nipples in Finnish home-bred sheep. Maat. Aikak. 17: 11-18.

17. W Assin, B., 1931. Linkage studies in sheep. J. Heredity 22: 9-13. 